\title{
EGFR NP_005219.2:p.V769_D770insGV
}

National Cancer Institute

\section{Source}

National Cancer Institute. EGFR NP 005219.2:p.V769 D770insGV. NCI Thesaurus. Code C98628.

An insertion of the amino acid sequence glycine-valine between the valine at position 769 and the aspartic acid at position 770 of the epidermal growth factor receptor protein. 